\title{
FAKTOR-FAKTOR YANG MEMPENGARUHI BID-ASK SPREAD PADA PERUSAHAAN MANUFAKTUR
}

\begin{abstract}
The amount of information asymmetry faced by dealers will be reflected in the spread. Dealers will try to maintain the bid-ask spreads are optimal, so the need to determine the factors that affect the bid-ask spread. This study aimed to analyze the effect of stock returns, trading volume, variants of stock returns and stock prices to bid-ask spread stock. The population in this study are manufacturing companies that publish financial statements in the period 2010-2012. The samples with purposive sampling, to obtain the 61 companies. From the data obtained were processed and analyzed using SPSS 19 o'clock, by means of multiple linear regression analysis. Multiple linear regression analysis was preceded with the classical assumption. The results showed that the first, the stock return significant negative effect on the bid-ask spread stock. Second, the volume of stock trading is not a significant positive effect on the bid-ask spread stock. Third, the stock price significant negative effect on the bid-ask spread stock. Fourth, variant stock returns are not significant positive effect terdahap stock bid-ask spread. Future studies could add other variables that stock price fluctuations (volatility) in the given period. Predicted volatility can affect the bid-ask spread stocks as investors memilliki enough information about the investment that not only perform certain transactions on the stock.
\end{abstract}

Keywords : stock returns, trading volume, variants of stock, returns, stock prices and stock bid-ask spread.

\section{PENDAHULUAN}

Pasar modal merupakan tempat bagi perusahaan untuk menghimpun dana yang berfungsi untuk membiayai secara langsung kegiatan perusahaan, masyarakat ikut serta langsung didalamnya. Fungsi pasar modal ada dua, yaitu fungsi ekonomi dan finansial. Fungsi ekonomi yaitu pasar modal memiliki kemampuan untuk menyalurkan dana secara efektif dan efisien dari pemilik modal kepada pihak yang membutuhkan. Sedangkan fungsi finansial yaitu pasar modal merupakan wadah untuk meningkatkan kesejahteraan pemilik modal melalui pembagian hasil (deviden) yang merupakan konpensasi atas dana yang telah ditanamkannya. Namun kondisi pasar modal yang sering tidak pasti menimbulkan risiko investasi yang harus dihadapi oleh para pelaku pasar modal. Untuk mengurangi ketidakpastian tersebut diperlukan sebuah informasi yang penting bagi pelaku pasar modal dalam mengambil keputusan. Sebenarnya unsur ketidakpastian atau risiko hampir terkandung dalam semua investasi. Dari investasi yang dilakukan, pemodal tidak tahu dengan hasil pasti yang diperoleh.

Mengingat investasi saham di pasar modal merupakan jenis investasi yang cukup berisikotinggi meskipun menjanjikan keuntungan yang relatif besar, maka perlu penilaian saham secara akurat agar meminimalkan risiko sekaligus membantu investor mendapat keuntungan yang wajar. Hal yang sering dijumpai yaitu semakin besar return yang diharapkan (expected), semakin besar pula peluang risiko yang terjadi, (Ambarwati, 2008).

Penelitian Kim dan Ismail (1996) dalam Ambarwati (2008) mengukur biaya informasi dengan 
menggunakan variabel bid-ask spread. Selisih antara bid price dengan ask price merupakan bid-ask spread. Harga tertinggi yang ditawarkan oleh dealer atau harga dimana spesialis atau dealer menawarkan untuk membeli saham yaitu bid price, sedangkan harga terendah dimana dealer bersedia untuk menjual saham yaitu ask price. Bid adalah harga yang diberikan saat kita akan membeli di satu pair mata uang. Ask adalah harga yang diberikan saat kita akan bertransaksi jual di satu pair mata uang. Spread adalah jarak antra nilai bid dan ask. Bid-ask spread adalah perbedaan harga beli atau jual pada satu waktu tertentu. Jarak atau perbedaan harga beli dan jual itu sering dijadikan indikasi likuiditas pasar yang artinya jika spread semakin berkurang maka semakin tinggi likuiditas keadaan pasar saat itu.

Stoll (1989) dalam Ambarwati (2008) menyatakan bahwa bid-ask spread berpengaruh positif terhadap biaya pemilikan. Artinya semakin lebar bid-ask spread saham akan menyebabkan semakin tinggi biaya pemilikan tersebut. Dengan volume perdagangan yang besar, menunjukan bahwa saham tersebut digemari oleh para investor yaitu perdagangan surat berharga yang aktif. Kondisi tersebut akan mendorong dealer untuk tidak memiliki saham dalam jangka waktu yang lama sehingga akan menurunkan biaya pemilikan. Makin rendah biaya pemilikan yang nantinya akan berdampak pada semakin kecilnya bid-ask spread maka dengan sendirinya semakin aktif perdagangan suatu saham atau semakin besar volume perdagangan.

Besarnya ketidakseimbangan informasi yang dihadapi dealer akan tercermin pada spread, dalam hal ini dealer sebagai partisipan pasar modal. Oleh karena itu, dengan mempertimbangkan kejadian tertentu atau kondisi informasi lainya sehubungan dengan sekuritas yang dimiliki dealer selalu berusaha menentukan spread secara wajar. Untuk mengatur perdagangan, pencatatan transaksi, administrasi, telepon, dan sebagainya diperlukan biaya berhubungan dengan biaya pemrosesan. Sedangkan biaya timbul karena adanya informasi asimetri para pelaku pasar modal adalah biaya informasi. Karena adanya informasi yang tidak dapat didistribusikan secara merata kepada semua pelaku di pasar modal maka timbulah informasi asimetri.

Pemegang peran penting dalam transaksi perdagangan dipasar modal yaitu informasi aktivitas perusahaan yang telah go public. Hal yang dapat mempengaruhi pengambilian keputusan investor dalam membeli atau menjual saham yaitu informasi yang dapat mempengaruhi naik turunnya harga saham, (Shobriati, 2013).

Salah satu sumber informasi keuangan perusahaan yang dapat digunakan sebagai dasar untuk membuat keputusan yaitu laporan keuanagan. Perubahan harga saham bisa juga disebabkan oleh perusahaan yang mempublikasikan laporan keuangan secara teoritis dan empiris, (Meythi, 2002) dalam Agustina (2012). Laporan keuangan yang memiliki kandungan informasi yang tinggi yaitu laba. Pihak internal maupun eksternal biasanya menggunakan informasi laba, (Yustan, 2007) dalam Agustina (2012). Kormedi dan Lipe (1987) dalam Agustina (2012) menguji hubungan antara return saham dengan inovasi earnings dan persistensi laba. Hasil penelitiannya menunjukan bahwa besarnya reaksi return saham perusahaan pada earnings harus dihubungkan dengan pengaruh inovasi earnings pada ekspektasi manfaat masa akan datang yang akan didapat pemegang saham, sehingga koefisien respon laba dengan return saham berkorelasi positif dengan persistensi laba dan tidak menunjukan sensitivitas yang berlebihan. Jadi dapat disimpulkan bahwa persistensi laba tergantung pada besarnya hubungan antara return saham dan earnings. 
Perusahaan, investor, kreditor, dan lain-lain sering menggunakan laba akuntansi sebagai ukuran kinerja, (Yustan, 2007) dalam Agustina (20120. Menurut Hermi (2011) kinerja keuangan yang bersangkutan akan dipengaruhi oleh variasi harga saham, permintaan, dan penawaran. Tinggi rendahnya harga saham dipasar modal ditentuka oleh kinerja keuangan. Pendapat Fuller dan Farrel (1987) dalam (Natarsyah, 2002) laba perusahaan dan dividen serta risiko gabungan kedua faktor yaitu kunci dari harga saham.

Penelitian terdahulu yang dilakukan oleh Nany (2003) pada 122 perusahaan tentang pengaruh harga saham, return saham, varian return saham, earnings, dan volume perdagangan terhadap bid-ask spread menyatakan bahwa harga saham berpengaruh negatif signifikan terhadap bid-ask spread, return saham berpengaruh negatif tidak signifikan terhadap bid-ask spread, varian return saham berpengaruh positif signifikan terhadap bid-ask spread, earnings berpengaruh negatif signifikan terhadap bid-ask spread, dan volume perdagangan saham berpengaruh negatigf signifikan terdap bid-askspread. Penelitian yang dilakukan Shobriati (2013) pada perusahaan yang terdaftar di BEl tentang pengaruh harga saham, volume perdagangan, dan varian return saham terhadap bid-ask spread menyatakan bahwa harga saham berpengaruh negatif signifikan terhadap bid-ask spread, voulume perdagangan saham brepengaruh negatif signifikn terhadap bid-ask spread, dan varian return saham berpengaruh positif signifikan terhadap bid-ask spread. Penelitian Ambarwati (2008) pada perusahaan manufaktur tentang pengaruh return saham, volume perdagangan, dan varian return saham terhadap bid-ask spread menyatakan bahwa return saham berpengaruh positif signifikan terhadap bid-ask spread, volume perdagangan saham berpengaruh negatif signifikan terhadap bid-ask spread, dan varian return saham berpengaruh positif signifikan terhadap bid-ask spread.

Penelitian Cahyono (2014) pada perusahaan manufaktur tentang pengaruh volume perdagangan saham dan return saham terhadap bid-ask sperad menyatakan bahwa volume perdagangan berpengaruh negatif tidak signifikan terhadap bid-ask spread, dan return saham berpengaruh negatif tidak signifikan terhadap bid-ask spread. Penelitian Chadijah (2010) pada perusahaan yang terdaftar di BEl tentang pengaruh harga saham, volume perdagangan saham, return saham terhadap bid-ask spread menyatakan bahwa harga saham berpengaruh negatif signifikan terhadap bid-ask spread, volume perdagangan berpengaruh positif tidak signifikan terhadap bid-ask spread, dan return saham berpegaruh negatif tidak signifikan terhadap bidask spread. Penelitian Dananjoyo (2011) pada perusahaan yang trgabung dalam BEJ tentang pengaruh return saham, volume perdagangan, dan varian return saham terhadap bid-ask spread menyatakan bahwa return saham berpengaruh positif signifikn terhadap bid-ask spread, volume perdagangan saham berpengaruh positif signifikan terhadap bid-ask spread,dan varian return saham berpengaruh positif signifikan terhadap bidask spread. Penelitian Purwanto (2004) pada perusahaan manufaktur tentang pengaruh harga saham, volume perdagangan saham,dan varian return saham terhadap bid-ask spread menyatakan bahwa harga saham berpengaruh negatif signifikan terhadap bid-ask spread, volume perdagangan berpengaruh negatif signifikan terhadap bid-ask spread, dan varian return saham berpengaruh positif signifikan terhadap bid-ask spread.

Riset-riset terdahulu yang hasilnya tidak searah, memotivasi untuk dilakukan penelitian lagi. Penelitian ini mengacu pada penelitian Ambarwati (2008). Perbedaan penelitian ini dengan Ambarwati (2008) terletak pada penambahan variabel independent yaitu harga saham. Permasalahan pada penelitian ini yaitu untuk 
membuktikan bahwa ada atau tidaknya pengaruh harga saham terhadap bid-ask spread saham, karena jika harga saham naik akan memberikan return yang tinggi, dapat diartikan bahwa saham tersebut disukai oleh investor, sehingga broker/dealer tidak perlu memegang saham tersebut terlalu lama, hal tersebut dapat menurunkan biaya pemilikan saham yang berarti mempersempit bid-ask spread saham. Jadi harga saham mempengaruhibid-ask spread. Selain itu penelitian ini juga menggunakan tahun penelitian yang berbeda dengan sebelumnya yaitu tahun 2010-2012, untuk menguji kekonsistenan hasil penelitian dengan penelitianpenelitian sebelumnya.

\section{KERANGKA TEORITIS DAN PENGEMBANGAN HIPOTESIS}

\section{Pengaruh Return Saham Terhadap Bid-Ask Spread}

Return juga merupakan laba investasi, baik melalui bunga ataupun dividen. Tingkat pengembalian saham adalah penghasilan yang diperoleh selama periode investasi per sejumlah dana yang diinvestasikan. Hal yang sering terjadi yaitu semakin besar return yang diharapkan (expected), maka semakin besar pula risiko yang terjadi. Dealermendapat kompensasi dalam membeli saham pada harga beli $(\mathrm{Pb})$ yang umumnya lebih rendah dari harga sebenarnya dan menjual pada harga jual (Pj) diatas harga sebenarnya (Pt). Spread yang didapat digunakan untuk menutup cost yang terjadi. Dengan demikian spread akan semakin rendah bila harga saham (return) tinggi, atau dengan kata lain return berpengaruh negatif terhadap spread (Stoll, 1978) dalam Ambarwati(2008) yang didukung oleh Cahyono (2014), dan Nany (2003). Berdasarkan uraian diatas maka dapat diperoleh hipotesis:

\section{H1 : Return Saham berpengaruh negatif signifikan terhadap Bid-Ask Spread}

\section{Pengaruh Volume Perdagangan Saham Terhadap Bid-Ask Spread}

Volume perdagangan yang besar, menunjukan bahwa saham tersebut digemari oleh para investor yang berarti saham tersebut cepat diperdagangkan merupakan perdagangan saham yang aktif.Volume perdagangan akan menurunkan kos pemilikan saham sehingga menurunkan spread. Dengan demikian semakin rendah biaya pemilikan saham tersebut yang berarti akan mempersempit bid-ask spread saham maka semakin aktif perdagangan suatu saham atau semakin besar volume perdagangan suatu saham tersebut. Nany (2003) dan Shobriati (2012) yang menunjukan volume perdagangan saham berpengaruh negatif signifikan terhadap bid-ask spread.Berdasarkan uraian diatas maka dapat diperoleh hipotesis :

\section{H2: Volume Perdagangan Saham berpengaruh negatif signifikan terhadap Bid-Ask Spread.}

\section{Pengaruh Varian Return Saham terhadap Bid-Ask Spread}

Varian return saham merupakan risiko saham yang dapat mempengaruhi besar kecilnya bid-ask spread saham. Pedagang yang memiliki informasi lebih banyak dapat memperoleh keuntungan, pada periode volatilitas harga saham yang tinggi. Hal tersebut mengakibatkan dealer/broker memperbesar keuntungan sebagai kompensasi atas resiko kerugian dengan meningkatkan spreadnya. Untuk menutupi resiko saham 
yang semakin tinggi maka dealer menggunakan spread yang lebih besar. Varian return berhubungan positif dipengaruhi oleh tinggi rendahnya bid-ask spread. Bid-ask spread mengalami peningkatan maka varian return mengalami kenaikan Purwanto (2004), Ambarwati (2008), Shobriati (2013) Nany (2003) dan Dananjoyo (2011) yang menunjukan bahwa varian return saham berpengaruh positif terhadap bid-ask spread.Berdasarkan uraian diatas maka dapat diperoleh hipotesis:

\section{H3 : Varian Return Saham berpengaruh positif signifikan terhadap Bid-Ask Spread.}

\section{Pengaruh Harga Saham Terhadap Bid-Ask Spread}

Harga saham yang tinggi dapat diartikan sebagai saham yang aktif diperdagangkan. Semakin meningkatnya harga saham merupakan kondisi ekonomi baik sehingga para pemodal menilai investasi dalam bentuk saham akan sangat menguntungkan, karena tidak menghadapi risiko. Sebaliknya jika kondisi ekonomi memburuk maka harga saham akan merosot jatuh dan keadaan tersebut tidak menguntungkan bagi para pemodal, sehingga para pemodal akan berhadapan dengan resiko lebih besar, karena berhubungan dengan ketidakpastian yang semakin besar (Purwanto, 2004). Harga saham memberikan return yang tinggi dapat diartikan bahwa saham tersebut disukai oleh investor, sehingga broker/dealer tidak perlu memegang saham tersebut terlalu lama, hal tersebut dapat menurunkan biaya pemilikkan saham yang berarti mempersempit bid-ask spread saham. Hasil-hasil penellitian Shobriati (2013), Purwanto (2004) dan Nany (2003) menunjukan bahwa harga saham berpengaruh negatif signifikan terhadap bid-ask spread.Berdasarkan uraian diatas maka dapat diperoleh hipotesis :

\section{H4 : Harga Saham berpengaruh negatif signifikan terhadap Bid-Ask Spread}

\section{Kerangka Pemikiran Teoritis}

Teori sinyal menjelaskan bahwa pemain saham atau investor perlu memiliki sejumlah informasi yang berkaitan dengan dinamika harga saham agar dapat mengambil keputusan tentang saham perusahaan yang layak untuk dipilih. Informasi keuangan perusahaan merupakan salah satu sumber yang dapat digunakan sebagai dasar untuk membuat keputusan yaitu laporan keuangan. Nilai perusahaan dipengaruhi oleh informasi yang akurat. Apabila terjadi asimetri informasi maka biaya informasi akan meningkat atau dengan kata lain bid-ask spreadnya meningkat. Tinggi rendahnya biasa informasi asimetri diketahui dari perubahan harga saham, perubahan volume perdagangan, return saham dan varian return saham. Kerangka pemikiran dapat disajikan dalam gambar 2.1 .

\section{METODE PENELITIAN}

Definisi operasional adalah definisi yang didasarkan atas sifat-sifat variabel yang diamati. Definisi operasional mencakup hal-hal penting dalam penelitian yang memerlukan penjelasan. Definisi operasional bersifat spesifik, rinci, tegas dan pasti yang menggambarkan karakteristik variabel-variabel.

\section{Return saham (Rt)}

Return saham merupakan imbalan atau keberanian investor menanggung resiko atas investasi yang 
dilakukan dan salah satu faktor yang memotifasi investor untuk berinvestasi. Hasil yang diperoleh dari investasi yaitu return. Return saham didefinisikan sebagai perubahan relatif harga saham dari periode sebelumnya (Jogiyanto, 2000) dalam Ambarwati (2008) yang dirumuskan:

$$
R t=\frac{\left(P_{t}-P_{t-1}\right) \times 100 \%}{P_{t-1}}
$$

Keterangan :

$\mathrm{R}_{\mathrm{t}} \quad=$ Return saham pada hari ke-t

$\mathrm{P}_{\mathrm{t}} \quad=$ Harga penutupan saham pada hari ke $(\mathrm{t})$

$\mathrm{P}_{\mathrm{t}-1} \quad$ = Harga penutupan saham pada hari ke $(\mathrm{t}-1)$

\section{Volume Perdagangan Saham}

Volume perdagangan merupakan jumlah lembar saham yang di perdagangkan pada hari tertentu (Abdul dan Nasuhi, 2000) dalam Ambarwati (2008). Volume perdagangan saham adalah keseluruhan nilai transaksi pembelian maupun penjualan saham dalam mata uang oleh investor. Untuk melihat apakah para investor individual menilai suatu informasi, maka digunakan aktivitas volume perdagangan, dalam arti apakah informasi tersebut membuat suatu keputusan pedagangan. Volume perdagangan saham $\left(\mathrm{V}_{\mathrm{t}}\right)$ didefinisikan sebagai jumlah lembar saham yang diperdagangkan pada hari ke-t.

\section{Varian Retun Saham}

Varian return saham merupakan risiko sering dihubungkan dengan penyimpangan atau deviasi dari outcome yang diterima dengan yang diekspektasi. Varian return saham juga merupakan risiko saham yang dapat mempengaruhi besar kecilnya bid-ask spread saham. Varian return saham mewakili risiko saham.rumus menghitung varianreturn:

$$
\sigma i^{2}=\frac{R_{i t}}{S t d D e v}
$$

Keterangan :

$\sigma \mathrm{i}^{2} \quad=$ varian return

$\mathrm{R}_{\text {it }} \quad=$ return ke-i pada periode $\mathrm{t}$

StdDev = standar deviasi

\section{Harga Saham}

Harga saham adalah harga pasar (market value) yaitu harga yang terbentuk di pasar jual beli saham yang artinya terlalu sedikitnya informasi yang mengalir di bursa saham cenderung mengakibatkan harga saham ditentukan tekanan spikologis pembeli atau penjual (Jogiyanto, 1998:69) dalam Chadijah (2010). Harga saham yang tinggi dapat diartikan sebagai saham yang aktif diperdagangkan. Semakin meningkatnya harga 
saham merupakan kondisi ekonomi baik sehingga para pemodal menilai investasi dalam bentuk saham akan sangat menguntungkan, karena tidak menghadapi risiko. Sebaliknya jika kondisi ekonomi memburuk maka harga saham akan merosot jatuh dan keadaan tersebut tidak menguntungkan bagi para pemodal, sehingga para pemodal akan berhadapan dengan resiko lebih besar, karena berhubungan dengan ketidakpastian yang semakin besar (Satiari, 2009). Harga saham yang naik akan menciptakan capitail gain, sedangkan harga saham yang turun akan menciptakan capitail loss. Harga saham pada penelitian ini yaitu harga saham yang tercatat setiap akhir periode setelah penutupan (closing price). Skala ukur yang digunakan untuk mengukur harga saham adalah skala rasio dengan satuan dalam rupiah (Rp).

\section{Bid-Ask Spread}

Bid-Ask Spread yaitu beda antara Ask price tertinggi dan Bid price terendah (Hartono, 1998:59) dalam Cahyono (2014). Selisih antara bid price tertinggi dengan ask price terendah yang terjadi pada waktu tertentu yaitu market spread. Spread adalah selisih point antara harga jual dan harga beli di pasar sekuritas.Bid-ask spread merupakan faktor yang dipertimbangkan investor untuk mengambil keputusan apakah menahan atau menjual saham tersebut. Bid-ask spread merupakan fungsi dari transaction cost, artinya dapat mempengaruhi perdagangan yang menyebabkan investor mengharapkan untuk menahan lebih panjang financial asset yang memiliki biaya transaksi yang lebih tinggi, (Fabozzi, 1999) dalam Satiari (2009).Spread tidak terlepas oleh adanya aktivitas yang dilakukan oleh anggota bursa yang dapat mempengaruhi besarnya transaksi sekuritas di pasar modal. Bid-ask spread relatif dirumuskan :

$$
R B A t=\frac{\left(H A_{t-1}-H B_{t+1}\right) \times 100 \%}{\frac{1}{2}\left(H A_{t=1}-H B_{t+1}\right) \times 100 \%}
$$

Keterangan :

$\mathrm{HA}_{\mathrm{t}} \quad=$ Harga ask pada hari ke $\mathrm{t}_{+1}$

$\mathrm{HB}_{\mathrm{t}} \quad=$ Harga bid pada hari ke $\mathrm{t}_{+1}$

$\mathrm{RBA}_{\mathrm{t}}=$ Bid-ask spread relatif pada hari ke- $\mathrm{t}$

\section{Populasi dan Sampel}

Objek perusahaan yang digunakan dalam penelitian ini adalah perusahaan go publik yang termasuk dalam kategori manufaktur yang terdaftar di Bursa Efek Indonesia (BEI). Periode penelitian yang diambil adalah tahun 2010-2012, selama periode penelitian total perusahaan manufaktur yang terdaftar sebanyak 146 perusahaan. Sampel dalam penelitian ini adalah perusahaan manufaktur di BEI tahun 2010-2012 yang aktif diperdagangan di BEl. Berdasarkan kriteria di atas, maka jumlah sampel adalah sebanyak 61 perusahaan. Distribusi pengambilan sampel disajikan pada Tabel 1.

Jumlah sampel dalam penelitian ini adalah 61 perusahaan, dengan sistem pooled cross sectional yaitu dengan menggabungkan data cross section selama 3 tahun berturut-turut (2010-2012), maka data diolah sebanyak 183. 


\section{Teknik Analisis}

Data yang dikumpulkan dalam penelitian ini dianalisis dengan alat statistik Regresi Linier Berganda, Variabelyang digunakan dalam penelitian initerdiridari satu variabel dependendan empat variabel independen. Pengujian hipotesis pertama dilakukan dengan melihat nilai koefisien regresi pada perhitungandalam model summary, yaitu Adjusted R Square. Interpretasinya adalah jika volume dan return dianggap konstan, maka bid-ask spread akan sama. Selain itu jika volume meningkat sebanyak satu satuan, maka bid-ask spread akan menurun, sedangkan jika return meningkat satu satuan, maka bid-ask spread menurun.

\section{HASIL DAN PEMBAHASAN}

\section{Pengujian Hipotesis}

Hasil pengolahan data dengan bantuan program SPSS 19, maka didapatkan model persamaan regresi akhir sebagai berikut :

$$
Y=0,065-0,274 X 1+0,174 X 2+0,001 X 3-5,0 E-007 X 4+e
$$

\section{Pengaruh Return Saham Terhadap Bid-Ask Spread}

Nilai koefisien regresi return saham bernilai negative dengan koefisien $\beta-0,274$ dan nilai signifikan sebesar 00,0\%. Return saham berpengaruh negatif signifikan terhadap bid-ask spread, kondisi ini terjadi karena return merupakan tingkat pengembalian saham, yaitu penghasilan yang di peroleh selama periode investasi per sejumlah dana yang diinvestasikan. Hal ini sering terjadi yaitu semakin besar return yang diharapkan, maka semakin besar pula risiko yang terjadi. Dealer mendapat kompensasi dalam membeli saham pada harga beli yang umumnya lebih rendah dari harga sebenarnya dan menjual pada harga jual di atas harga sebenarnya. Spread yang di dapat digunakan untuk menutup cost yang terjadi. Dengan demikian spread akan semakin rendah bila harga saham (return) tinggi atau dengan kata lain return berpengaruh negatif terhadap spread.

Hasil ini mendukung penelitian yang dilakukan oleh Stoll dalam Ambarwati (2008) yang menyatakan bahwa return saham berpengaruh negatif signifikan terhadap bid-ask pread. Hasil ini konsisten dengan penelitian yang dilakukan oleh Cahyono (2014) dan Nany (2003) yang menyatakan bahwa return saham berpengaruh negatif signifikan terhadap bid-ask pread.

\section{Pengaruh Volume Perdagangan saham Terhadap Bid-Ask Spread}

Nilai koefisien regresi volume perdagangan saham bernilai positif sebesar $\beta 0,174$ dan nilai signifikan sebesar 23,8\%. Volume perdagangan saham berpengaruh positif tidak signifikan terhadap bid-ask spread, kondisi ini terjadi karena volume perdagangan saham yang tinggi atau rendah belum tentu mempengaruhi bid-ask spread saham, sebab apabila harga saham rendah namun saham yang diperdagangan banyak, hal tersebut tidak akan menghasilkan cost yang tinggi, sehingga akan menurunkan bid-ask spread yang artinya volume perdagangan saham tidak mempunyai pengaruh signifikan terhadap bid-ask spread saham.

Hasil ini mendukung penelitian Chadijah (2010) yang menyatakan volume perdagangan saham berpengaruh positif tidak signifikan terhadap bid-ask spread, sehingga tinggi rendahnya volume perdagangan 
saham tidak mempengaruhi bid-ask spread.

\section{Pengaruh Varian Return Saham Terhadap Bid-Ask Spread}

Nilai koefisien regresi varian return saham bernilai positif sebesar $\beta$ 0,001dan nilai signifikan sebesar $63,4 \%$. Varian return saham berpengaruh positif tidak signifikan terhadap bid-ask spread, kondisi ini terjadi karena besar kecilnya bid-ask spread saham tidak dipengaruhi oleh varian return saham yang merupakan risiko saham. Varian return berkorelasi dengan risiko, sehingga varian return yang tinggi berarti risiko yang dihadapi juga tinggi. Besarnya risiko membuat biaya kepemilikan saham semakin tinggi yang berarti dapat memperlebar bid-ask spread saham, hal tersebut terjadi karena dealer tidak langsung melepas saham tetapi saham ditahan terlebih dahulu sampai pada waktu tertentu, yang artinya risiko yang semakin tinggi tidak membuat dealer menaikan biaya kepemilikan, sehingga bid-ask spread tetap kecil.

Hasil penelitian ini tidak mendukung pada penelitian Ambarwati (2010), Chadijah (2010), Dananjoyo (2010) menyatakan bahwa varian return saham berpengaruh positif tidak signifikan terhadap bid-ask spread.

\section{Pengaruh Harga Saham Terhadap Bid-Ask Spread}

Nilai koefisien regresi harga saham bernilai negatif sebesar $\beta-5,0 \mathrm{E}-007$ dan nilai signifikan sebesar 04,8\%. Harga saham berpengaruh negatif signifikan terhadap bid-ask spread, kondisi ini terjadi karena harga saham yang tinggi dapat diartikan sebagai saham yang aktif diperdagangkan. Semakin meningkat harga saham menandakan kondisi ekonomi baik sehingga para pemodal menilai investasi dalam bentuk saham akan sangat menguntungkan, karena tidak menghadapi risiko.

Hasil ini mendukung penelitian Shobriati (2013), Purwanto (2004) dan Nany (2003) yang menunjukkan bahwa harga saham berpengaruh negatif signifikan terhadap bid-ask spread.

\section{SIMPULAN}

Berdasarkan hasil penelitian yang telah dilakukan, maka dapat dibuat saran sebagai berikut : (1) Return saham berpengaruh negatif signifikan terhadap bid-ask spread, kondisi ini terjadi karena semakin besar return yang diharapkan, maka semakin besar pula risiko yang terjadi. Spread yang di dapat digunakan untuk menutup cost yang terjadi. Return saham berpengaruh negatif signifikan terhadap bid-ask spread saham. (2) Volume perdagangan saham berpengaruh positif tidak signifikan terhadap bid-ask spread, kondisi ini terjadi karena bila harga saham rendah tetap volume perdagangan saham yang diperdagangan banyak tidak akan menghasilkan cost yang tinggi, sehingga akan menurunkan bid-ask spread saham. Volume perdagangan saham berpengaruh positif tidak signifikan terhadap bid-ask spread. (3) Varian return saham berpengaruh positif tidak signifikan terhadap bid-ask spread, kondisi ini terjadi karena dealer tidak langsung melepas saham sekalipun harga saham tinggi, tetapi saham ditahan terlebih dahulu sampai pada waktu tertentu. Dengan demikian risiko yang semakin tinggi membuat dealer menaikan biaya kepemilikan sehingga bid-ask spread saham tetap kecil. (4) Harga saham berpengaruh negatif signifikan terhadap bid-ask spread, kondisi ini terjadi karena harga 
saham yang tinggi dapat diartikan sebagai saham yang aktif diperdagangkan. semakin meningkatnya harga saham merupakan kondisi ekonomi baik sehingga para pemodal menilai investasi dalam bentuk saham akan sangat menguntungkan, kerena tidak menghadapi risiko.

\section{Saran}

Berdasarkan penelitian terdapat saran bagi : (1) Pihak investor bisa mempertimbangkan variabel harga saham dan return saham apabila akan menanamkan modalnya di perusahaan tersebut, karena ini akan memperkecil bid-ask spread, dan pada akhirnya akan mempengaruhi tingkat pengembalian investasi yang lebih menguntungkan. (2) Pihak manajemen bisa membuat harga saham dan return saham meningkat dengan menjaga kinerja perusahaan dan hasil kinerja yang baik. Apabila hal ini terjadi, maka keuntungan investor bisa meningkat dan investor percaya kepada perusahaan untuk menanamkan modalnya.

\section{Keterbatasan}

Keterbatasan dalam penelitian ini adalah variabel bebas (return saham, volume perdagangan saham, varian return saham dan harga saham) dalam penelitian ini hanya dapat menjelaskan 49,60 \% bid ask spread.

\section{Agenda Penelitian Yang Akan Datang}

Penelitian selanjutnya juga bisa menambah variabel bebas lain yang mempengaruhi bid-ask spread seperti faktor eksternal perusahaan, volatilitas yaitu fluktuasi harga saham pada periode tertentu. Volatilitas diprediksi dapat mempengaruhi bid-askspread karena investor memiliki informasi yang cukup tentang investasi sehingga tidak hanya melakukan transaksi pada saham tertentu saja. Variabel volatilitas harga saham mewakili tinggi risiko suatu saham yang menunjukan bahwa semakin tinggi risiko suatu saham menyebabkan dealer tidak tahan lama menahan saham, sehingga biaya kepemilikan saham menjadi menurun yang menyebabkan menyempitnya bid-ask spread saham. Dengan demikian dapat dikatakan bahwa volatilitas harga saham berpengaruh negatif tidak signifikan terhadap bid-ask spread saham, Napitupulu (2013).

\section{DAFTAR PUSTAKA}

Agustina, Lidya dan Ferlysia Kianti. 2012. Pengaruh Informasi Laba Akuntansi Terhadap Abnormal Return Pada Perusahaan Yang Tergabung Dalam Indeks LQ 45. Jurnal Akuntansi. Vol, 4. No, 2.

Agustina, Lidya. 2012. Pengaruh Informasi Laba Akuntansi Terhadap Abnormal Return Pada Perusahaan Yang Tergabung Dalam Indeks LQ 45. Jurnal Akuntansi. Vol, 4. No, 2.

Ambarwati, Sri Dwi Ari. 2008. Pengaruh Return Saham, Volume Perdagangan Saham, dan Varian Return Saham

Terhadap Bid-Ask Spread Saham Pada Perusahaan Manufaktur Yang Tergabung Dalam Indeks LQ 45 Tahun 2003-2005. Jurnal Siasat Bisnis. Vol, 12. No, 1.

Cahyono, Yuli Tri. 2014. Volume Perdagangan dan Return Saham Dalam Hubungannya Dengan Bid-Ask Pada Perusahaan Go Public. Seminar Nasional dan Call Paper Program Studi Akuntansi-FEB UMS. 
Chadijah, Siti. 2010. Analisi Pengaruh Harga, Volume Perdagangan, Return, Frekuensi Perdagangan, dan Volatilitas Harga Saham terhadap Bid-Ask Spread Perusahaan Yang Melakukan Stock Split Periode 2004-2008. Skripsi. Universitas Islam Negri Syarif Hidayatullah. Jakarta.

Dananjoyo, Thomas Morulo. 2011. Pengaruh Return Saham, Volume Perdagangan Saham, dan Varian Return Saham Terhadap Bid-Ask Spread Saham di BEI Periode 2006-2010. Skripsi. Universitas Atma Jaya. Yogyakarta. Haniati, Sri dan Fitriany. 2010. Pengaruh Konservatisme Terhadap Asimetri Informasi Dengan Menggunakan Beberapa Model Pengukuran Konservatisme. Simposium Nasional Akuntansi 13. Purwokerto.

Hermi. 2011. Pengaruh Kinerja Keuangan Terhadap Return Saham Pada Perusahaan Manufaktur Yang Terdaftar di BEl Periode Tahun 2008-2010. Jurnal Informasi, Perpajakan, Akuntansi dan Keuangan Publik. Vol, 6. No, 2.

Indriantoro, Nur dan Bambang Supomo. 2012. Metodologi Penelitian Bisnis, Edisi pertama. Yogyakarta: BPFE UGM.

Nany, Magdalena. 2003. Analisi Pengaruh Harga Saham, Return Saham, Varian Retur Saham, Earnings dan Volume Perdagangan Saham Terhadap Bid-Ask Spread Pra dan Pasca Pengumuman Laporan Keuangan. Tesis. Universita Diponegoro. Semarang.

Napitupulu, Veronica dan Syahyunan. 2013. Pengaruh Return Saham, Volume Perdagangan Saham, dan Volatilitas Harga Saham Terhadap Bid-Ask Spread Saham Pada Perusahaan yang Melakukan stock Split di BEI. Jurnal Akuntansi. Vol, 1. No, 2.

Natarsyah, S. 2002. Analisis Pengaruh Beberapa Faktor Fundamental dan Risiko Sistematik Terhadap Harga Saham. Bunga Rampai Kajian Teori Keuangan. Yogyakarta: BPFE

Perangin-angin, Novita Selsia M dan Syarief Fauzie. 2013. Analisi Pengaruh Bid-Ask Spread, Market Value, Variance Return terhadap Holding Period Saham Sektor Pertambangan. Jurnal Ekonomi dan Keuangan. Vol, 1 . No, 3.

Purwanto, agus. 2004. Pengaruh Harga Saham, Volume Perdagangan, dan Varian Return Terhadap Bid-Ask Spread Pada Masa Sebelum dan Sesudah Right Issue Di Bursa Efek Jakarta Periode 2000-2002. Jurnal Akuntansi dan Auditing. Vol, 1. No, 1.

Ridhmadhantia, Chandra Devi. 2010. Analisis Pengaruh Surprise Earnings Announcemet terhadap Return Saham dan Dividend Payout Dengan Uji Beda Positiv Earnings Surprise dan Negatif Earnings Surprise Pada Perusahaan LQ 45 di BEI. Skripsi. Universitas Islam Negri Syarif Hidayatullah. Jakarta.

Satiara, Fitria. 2009. Analisis Perbedaan Sistem Fraksi Harga Saham Terhadap Variabel Bid-Ask Spread, Depth, dan Volume Perdagangan. Tesis. Universitas Diponegoro. Semarang.

Shobriati, Ikrima dan dkk. 2013. Pengaruh Harga Saham, Volume Perdagangan Saham, Varian Return Terhadap Bid-Ask Spread di Seputar Pengumuman Stock Split. Jurnal Ekonomi. Vol, 5. No, 2.

Wibiwo, Purwo Adi. 2005. Analisi Perbedaan Variabilitas Keuntungan Saham, Aktivitas Perdagangan Saham, dan Bid-Ask Spread Sebelum dan Sesudah Stock Split. Jurnal Dinamika Bisnis dan Ekonomi. Vol, 2. No, 1. 


\section{Lampiran 1}

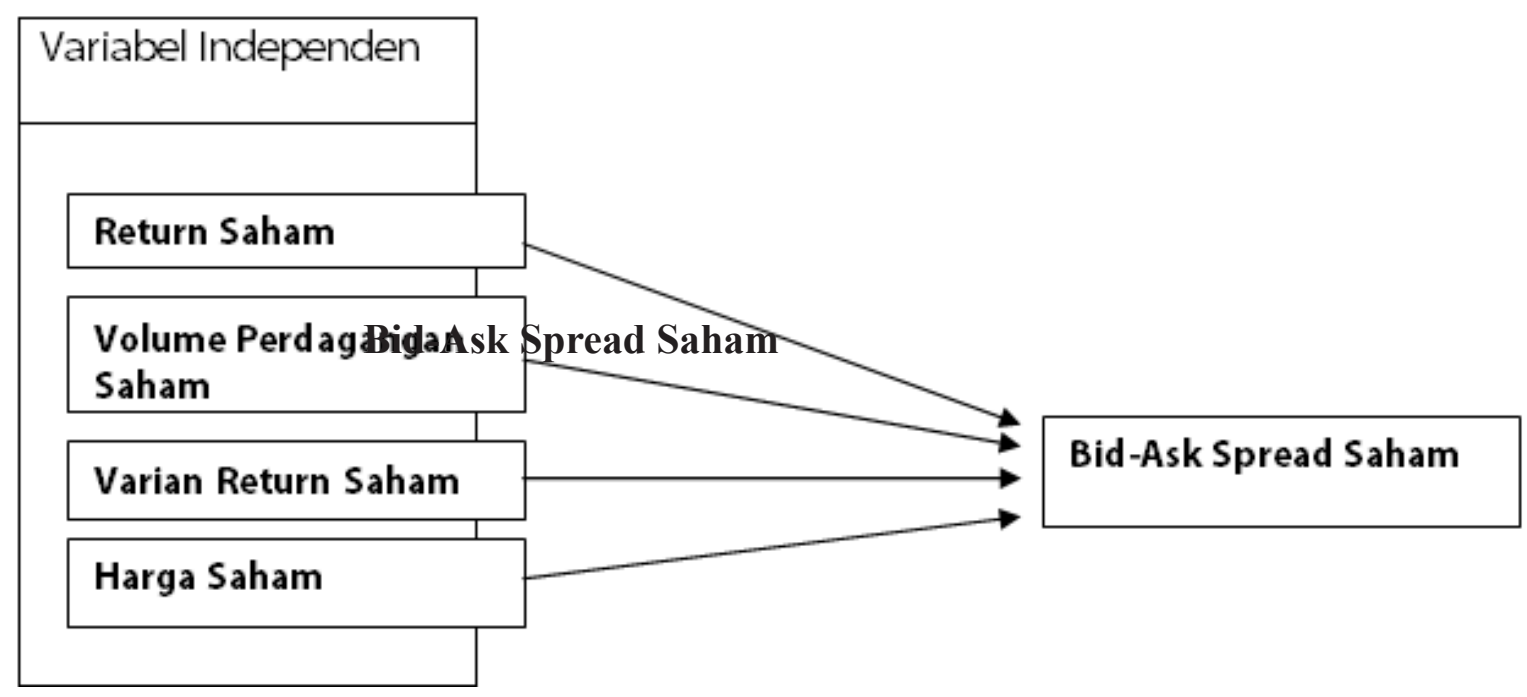

Gambar 1.

Kerangka Pemikiran Teoritis

\section{Lampiran 2}

Tabel 1.

Distribusi Sampel

\begin{tabular}{ll}
\hline Keterangan & Jumlah sampel \\
\hline Perusahaan manufaktur yang terdaftar di BEl tahun 2010-2012 & 440 Perusahaan \\
\hline Perusahaan yang tidak aktif di perdagangan di BEl tahun 2010-2012 & (233 perusahaan) \\
\hline Perusahaan manufaktur yang datanya tidak lengkap di BEl tahun 2010-2012 & (24 perusahaan ) \\
\hline Jumlah sampel & 183 Perusahaan \\
\hline
\end{tabular}




\section{Lampiran 3}

Tabel 2.

Model Persamaan Regresi Berganda

\section{Coefficientsa}

\begin{tabular}{|c|c|c|c|c|c|c|}
\hline \multirow{2}{*}{\multicolumn{2}{|c|}{ Model }} & \multicolumn{2}{|c|}{$\begin{array}{c}\text { Unstandardized } \\
\text { Coefficients }\end{array}$} & \multirow{2}{*}{$\begin{array}{c}\text { Standardized } \\
\text { Coefficients }\end{array}$} & \multirow[b]{2}{*}{$\mathrm{t}$} & \multirow[b]{2}{*}{ Sig. } \\
\hline & & $\mathrm{B}$ & Std. Error & & & \\
\hline \multirow[t]{5}{*}{1} & (Constant) & ,065 & ,021 & & 3,051 &, 003 \\
\hline & Return Saham &,- 274 & 022 &,- 704 & $-12,641$ & ,000 \\
\hline & $\begin{array}{l}\text { Volume perdagangan } \\
\text { saham }\end{array}$ & 174 & 147 & ,065 & 1,185 & ,238 \\
\hline & Varian Return Saham & ,001 & ,003 & ,026 & ,477 & ,634 \\
\hline & Harga saham & $-5,0$ E-007 & ,000 &,- 109 & $-1,994$ & ,048 \\
\hline
\end{tabular}

a. Dependent Variable: Bid Ask Spread 
